\title{
Characterization of Asiatic Lily Genotypes for Flowering and Quality Parameters under Protected Conditions
}

\author{
S.Y. Chandrashekar ${ }^{1 *}$, B. Hemla Naik ${ }^{2}$, Balaji S. Kulkarni ${ }^{3}$ and R.C. Jagadeesha ${ }^{4}$
}

${ }^{1}$ Department of Floriculture and Landscape Architecture, College of Horticulture, Mudigere, Chikmagalur-577132, Karnataka, India

${ }^{2}$ Department of Horticulture, College of Agriculture, Navile, Shivamogga - 577225, Karnataka, India

${ }^{3}$ Department of Floriculture and Landscape Architecture, College of Horticulture, GKVK, Bangalore-65, Karnataka, India

${ }^{4}$ Department of CIB, UHS, Bagalkot, Karnataka, India

*Corresponding author

\section{A B S T R A C T}

The present investigations were carried out in the experimental block of the department of

Keywords

Asiatic lily,

Genotypes, Floral

parameters,

Protected condition

Article Info

Accepted:

04 August 2018

Available Online:

10 September 2018
Floriculture and Landscape Architecture, College of Horticulture, Mudigere, Chikmagalur, Karnataka to characterize the Asiatic lily genotypes for flowering and quality of cut flowers under naturally ventilated polyhouse. The days taken for flower bud emergence were significantly differed among all the genotypes of Asiatic lily. The genotype Telisker was the earliest to show colour by taking (35.00 days) whereas, Ercolania (48.67 days) was late for expressing colour in its flower. The genotype Pirandeu was the earliest to show colour by taking minimum number of days followed by Telisker. The genotype Merluza $(19.51 \mathrm{~cm})$ followed by Courier $(19.34 \mathrm{~cm})$ produced significantly bigger sized flowers than any other genotypes. The genotypes viz., Pirandeu, CEB Dazzle, Dazzle, Courier, Pavia and Tresor recorded maximum number of spikes per square meter(24.00) while, the genotype Batistero recorded the minimum number (16.67). The genotype Pirandeu extended its vase life maximum up to (12.37 days) and found significantly superior over other genotypes and it was found to be on par with Pavia (12.17 days) whereas, the minimum number of days was recorded in Navona (7.73 days).

\section{Introduction}

The Lilies belongs to genus Lilium of Liliaceae family, consist of about 80-100 species distributing in the northern hemisphere (Eurasia and North America continent). All Lilium species are diploid $(2 \mathrm{n}=2 \mathrm{x}=24)$, except some triploid forms of L. tigrinum and $\mathrm{L}$. bulbiferum existing in nature. The genome size of Lilium belongs to one of the largest in plant kingdom.

The two important distribution centers of lily are South-East Asia (China, Korean peninsula and Japan) and North America are with 61 and 21 species, respectively and the number of 
native European and Eurasian species is approximately 10 (Van et al., 2011).

\section{Materials and Methods}

The present investigations were carried out in the experimental block of the department of Floriculture and Landscape Architecture, College of Horticulture, Mudigere, Chikmagalur, Karnataka to characterize the Asiatic lily for cut flower yield and quality under naturally ventilated polyhouse. Fifteen Asiatic lily genotypes were procured from M/S Florence Flora, Bangalore and M/S Sheel Biotech, New Delhi. The name and colour of these fifteen genotypes are presented in the Table 1. The experiment was laid out in randomized complete block design (RCBD) with three replications. The size of the experimental plot was $2.5 \mathrm{~m} \mathrm{x} 1 \mathrm{~m}\left(2.5 \mathrm{~m}^{2}\right)$. The healthy, uniform sized $(12-14 \mathrm{~cm}$ diameter) bulbs of fifteen Asiatic lily genotypes were planted at a depth of $10 \mathrm{~cm}$ in each plot with 30 X $15 \mathrm{~cm}$ spacing.

The recommended dose of FYM @ 4 kg per $\mathrm{m}^{2}$ and $\mathrm{N}, \mathrm{P}$ and $\mathrm{K}\left(10: 15: 20 \mathrm{~g} / \mathrm{m}^{2}\right)$ fertilizers were applied in the form of urea $(46.40 \% \mathrm{~N})$, rock phosphate $\left(28.00 \% \mathrm{P}_{2} \mathrm{O}_{5}\right)$, muriate of potash $\left(60.00 \% \mathrm{~K}_{2} \mathrm{O}\right)$, respectively. The basal dose of 50 per cent of NPK was applied at the time of planting, while remaining 50 per cent of NPK was applied in 5 split doses at different crop growth stages. A secondary nutrient like Calcium was applied as basal dose in the form of Calcium Ammonium Nitrate to soil at the rate of $30 \mathrm{~g} / \mathrm{m}^{2}$.

\section{Results and Discussion}

The data pertaining to flowering characters like days taken to colour visibility and days taken to 50 per cent flowering are furnished in Table 2 and Figure 1. The days taken for visibility of colour in flower bud from planting varied significantly among different genotypes. The genotype Telisker was the earliest to show colour by taking (35.00 days) whereas, Ercolania (48.67 days) was late for expressing colour in its flower. The days taken for 50 per cent flowering varied significantly among different genotypes of Asiatic lily. The genotype Pirandeu was the earliest to put forth 50 per cent flowering (43.00 days) which was followed by genotype Courier (44.00 days), while the genotype Merluza (64.00 days) was late to put forth 50 per cent flowering. These variations for flower bud initiation may be attributed to genetic make-up and physiological differences among the genotypes as reported earlier by Dhiman (2003), Sindhu (2006) and Pandey et al., (2010).

The genotype Pirandeu was found to be the earliest to put forth 50 per cent flowering which was followed by genotype Telisker. The variation in floral characters may be attributed to the genetic make-up of plants. Wide variation in floral parameters has also been reported by Dhiman (2003), Sindhu (2006), Chitra and Rajamani (2009) and Pandey et al., (2010). The days taken to flowering was also affected by duration of cold storage of bulbs. As the cold storage was extended the variation in time to flowering decreased. The results are in agreement with the findings of Wilfret and Raulston (1971). The data pertaining to different flower quality parameters viz., flower bud diameter $(\mathrm{mm})$, flower diameter $(\mathrm{cm})$, stalk length $(\mathrm{cm})$ and vase life (days) are presented in Table 3 and Figure 2.

The results indicated that, significant differences were observed for bud diameter of different Asiatic lily genotypes. It was maximum in the genotype Merluza (25.96 $\mathrm{mm}$ ) and was found on par with Courier $(23.92 \mathrm{~mm})$ followed by Mestre $(23.60 \mathrm{~mm})$ whereas, Tresor recorded minimum (17.46 $\mathrm{mm}$ ) bud diameter. 
Table.1 Colour characteristics of 15 Asiatic lily genotypes

\begin{tabular}{|l|c|l|}
\hline \multicolumn{1}{|c|}{ Genotypes } & Colour & \multicolumn{1}{c|}{ Source } \\
\hline Advantage & Orange & M/S Florence Flora, Bangalore \\
\hline Bright Diamond & White & M/S Florence Flora, Bangalore \\
\hline CEB Dazzle & Yellow & M/S Sheel Biotech, New Delhi \\
\hline Dazule & Yellow & M/S Florence Flora, Bangalore \\
\hline Courier & White & M/S Florence Flora, Bangalore \\
\hline Mestre & Light pink & M/S Florence Flora, Bangalore \\
\hline Telisker & Orange & M/S Sheel Biotech, New Delhi \\
\hline Batistero & Red & M/S Sheel Biotech, New Delhi \\
\hline Pirandeu & White & M/S Sheel Biotech, New Delhi \\
\hline Merluza & Med & M/S Sheel Biotech, New Delhi \\
\hline Fangio & Yellow & M/S Sheel Biotech, New Delhi \\
\hline Pavia & White & M/S Florence Flora, Bangalore \\
\hline Ercolania & Orange & M/S Sheel Biotech, New Delhi \\
\hline Tresor & White & M/S Sheel Biotech, New Delhi \\
\hline Navona
\end{tabular}

Table.2 Performance of different Asiatic lily genotypes for flowering parameters under protected condition

\begin{tabular}{|c|l|c|c|}
\hline Treatment & Genotypes & Days to colour visibility & Days to 50 per cent flowering \\
\hline $\mathrm{T}_{1}$ & Advantage & 43.33 & 57.33 \\
\hline $\mathrm{T}_{2}$ & Bright Diamond & 42.67 & 57.00 \\
\hline $\mathrm{T}_{3}$ & CEB Dazzle & 46.67 & 62.67 \\
\hline $\mathrm{T}_{4}$ & Dazzle & 44.67 & 61.33 \\
\hline $\mathrm{T}_{5}$ & Courier & 37.67 & 44.00 \\
\hline $\mathrm{T}_{6}$ & Mestre & 45.00 & 61.33 \\
\hline $\mathrm{T}_{7}$ & Telisker & 27.00 & 45.33 \\
\hline $\mathrm{T}_{8}$ & Batistero & 35.67 & 53.33 \\
\hline $\mathrm{T}_{9}$ & Pirandeu & 35.00 & 43.00 \\
\hline $\mathrm{T}_{10}$ & Merluza & 43.33 & 64.00 \\
\hline $\mathrm{T}_{11}$ & Fangio & 44.67 & 62.67 \\
\hline $\mathrm{T}_{12}$ & Pavia & 46.00 & 63.00 \\
\hline $\mathrm{T}_{13}$ & Ercolania & 48.67 & 63.00 \\
\hline $\mathrm{T}_{14}$ & Tresor & 45.67 & 60.67 \\
\hline $\mathrm{T}_{15}$ & Navona & 45.33 & 58.67 \\
\hline & SEm \pm & 0.95 & 1.29 \\
\hline & C.D. $(\mathrm{P}=0.05)$ & 2.74 & 3.73 \\
\hline
\end{tabular}


Table.3 Performance of different Asiatic lily genotypes for flower quality under protected condition

\begin{tabular}{|c|l|c|c|c|c|}
\hline Treatment & \multicolumn{1}{|c|}{$\begin{array}{c}\text { Genotypes } \\
\text { diameter }(\mathbf{m m})\end{array}$} & $\begin{array}{c}\text { Flower } \\
\text { diameter }(\mathbf{c m})\end{array}$ & $\begin{array}{c}\text { Stalk length } \\
(\mathbf{c m})\end{array}$ & $\begin{array}{c}\text { Vase life } \\
\text { (days) }\end{array}$ \\
\hline $\mathrm{T}_{1}$ & Advantage & 19.20 & 17.71 & 50.57 & 8.27 \\
\hline $\mathrm{T}_{\mathbf{2}}$ & Bright Diamond & 19.86 & 16.97 & 67.77 & 9.25 \\
\hline $\mathrm{T}_{3}$ & CEB Dazzle & 18.85 & 17.69 & 65.63 & 10.33 \\
\hline $\mathrm{T}_{4}$ & Dazzle & 17.75 & 17.15 & 61.63 & 10.37 \\
\hline $\mathrm{T}_{5}$ & Courier & 23.92 & 19.34 & 54.47 & 9.37 \\
\hline $\mathrm{T}_{\mathbf{6}}$ & Mestre & 23.60 & 18.09 & 75.87 & 9.27 \\
\hline $\mathrm{T}_{\mathbf{7}}$ & Telisker & 18.73 & 18.28 & 67.43 & 11.27 \\
\hline $\mathrm{T}_{8}$ & Batistero & 20.34 & 16.70 & 59.67 & 10.23 \\
\hline $\mathrm{T}_{9}$ & Pirandeu & 19.19 & 18.27 & 49.77 & 12.37 \\
\hline $\mathrm{T}_{10}$ & Merluza & 25.96 & 19.51 & 56.57 & 10.23 \\
\hline $\mathrm{T}_{11}$ & Fangio & 19.54 & 16.41 & 57.87 & 8.23 \\
\hline $\mathrm{T}_{12}$ & Pavia & 18.87 & 18.79 & 48.93 & 12.17 \\
\hline $\mathrm{T}_{13}$ & Ercolania & 19.05 & 18.68 & 52.53 & 8.20 \\
\hline $\mathrm{T}_{14}$ & Tresor & 17.46 & 17.27 & 45.00 & 8.23 \\
\hline $\mathrm{T}_{15}$ & Navona & 18.58 & 16.41 & 34.77 & 7.73 \\
\hline & SEm \pm & 1.53 & 0.58 & 2.01 & 0.59 \\
\hline & C.D. $(\mathrm{P}=0.05)$ & 4.42 & 1.67 & 5.84 & 1.72 \\
\hline
\end{tabular}

Table.4 Performance of different Asiatic lily genotypes for flower Yield under protected condition

\begin{tabular}{|c|l|c|c|}
\hline Treatment & Genotypes & Number of florets/spike & Number of spikes $/ \mathbf{m}^{2}$ \\
\hline $\mathrm{T}_{1}$ & Advantage & 2.80 & 23.33 \\
\hline $\mathrm{T}_{2}$ & Bright Diamond & 3.20 & 23.33 \\
\hline $\mathrm{T}_{3}$ & CEB Dazzle & 4.87 & 24.00 \\
\hline $\mathrm{T}_{4}$ & Dazzle & 4.40 & 24.00 \\
\hline $\mathrm{T}_{5}$ & Courier & 2.80 & 24.00 \\
\hline $\mathrm{T}_{6}$ & Mestre & 3.93 & 23.33 \\
\hline $\mathrm{T}_{7}$ & Telisker & 3.47 & 23.67 \\
\hline $\mathrm{T}_{8}$ & Batistero & 2.93 & 16.67 \\
\hline $\mathrm{T}_{9}$ & Pirandeu & 5.00 & 24.00 \\
\hline $\mathrm{T}_{10}$ & Merluza & 2.93 & 22.00 \\
\hline $\mathrm{T}_{11}$ & Fangio & 3.20 & 21.33 \\
\hline $\mathrm{T}_{12}$ & Pavia & 4.53 & 24.00 \\
\hline $\mathrm{T}_{13}$ & Ercolania & 3.93 & 23.67 \\
\hline $\mathrm{T}_{14}$ & Tresor & 3.60 & 24.00 \\
\hline $\mathrm{T}_{15}$ & Navona & 4.27 & 19.33 \\
\hline & SEm \pm & 0.26 & 0.97 \\
\hline & CD @ 5\% & 0.75 & 2.80 \\
\hline
\end{tabular}


Fig.1 Performance of different Asiatic lily genotypes for flowering Parameters under protected condition

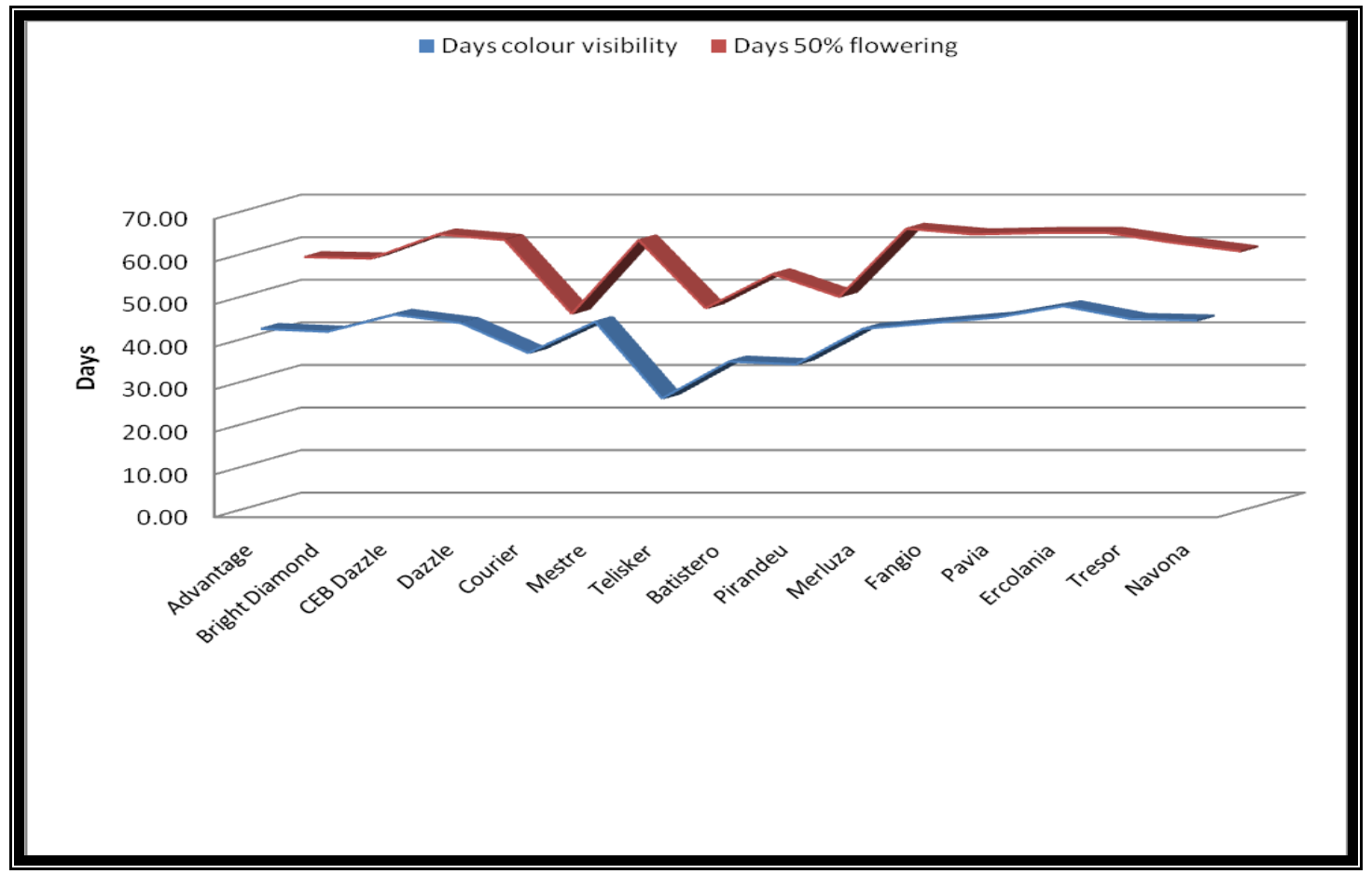

Fig.2 Performance of different Asiatic lily genotypes for vase life Grown under protected condition

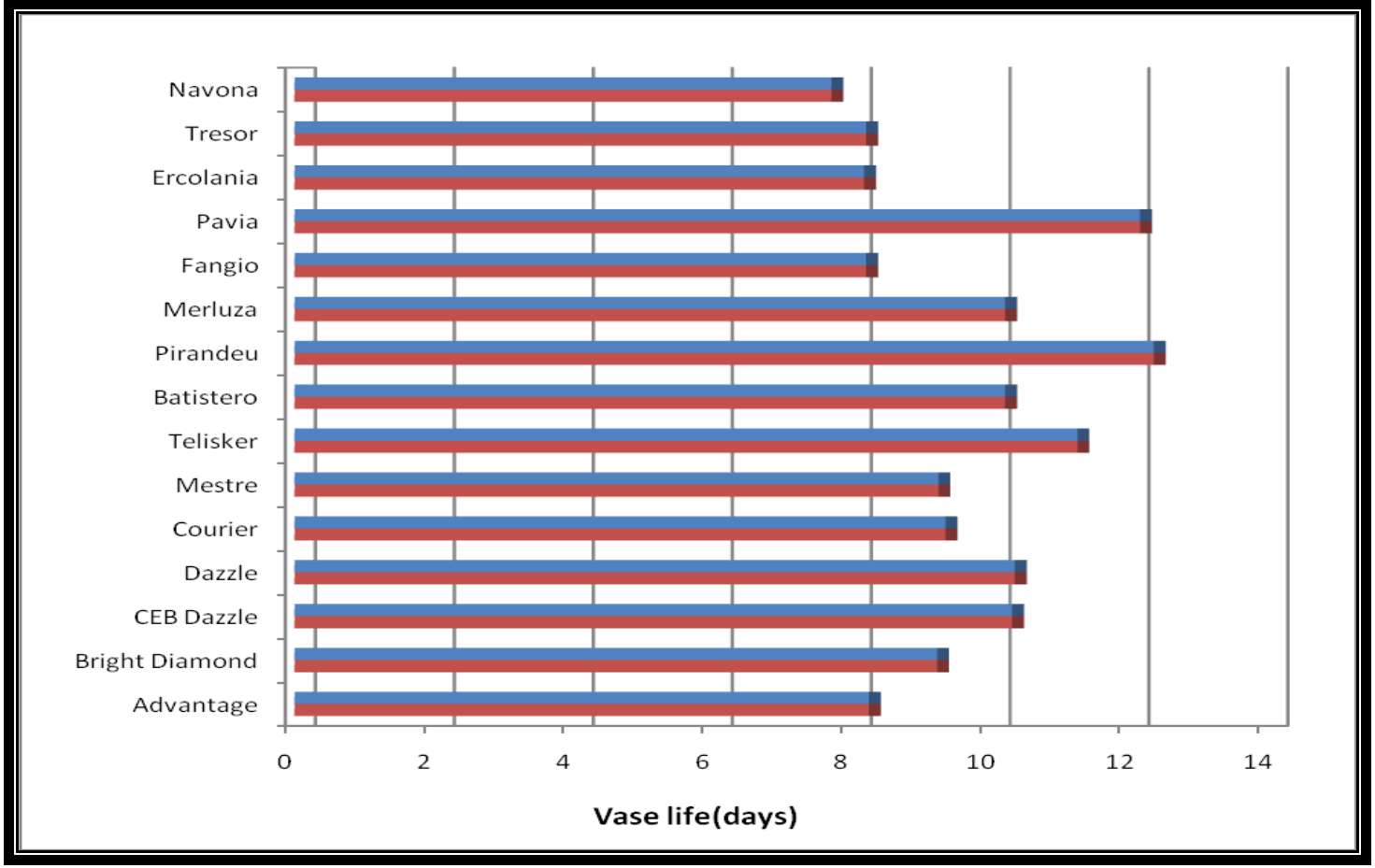


The variations in the bud diameter might be due to the thickness of petals and also due to the inherent characters. Varying amount of differences was recorded among the different Asiatic lily genotypes for flower stalk length. It was maximum in the genotype Mestre which was superior over other genotypes.

The stalk length is very important parameter in Asiatic lily cut flowers. It is one of the characters which decide the quality of cut flowers. This difference among the genotypes of Asiatic lily might be due to their genetic characters of particular genotype.

Significant differences were observed with respect to flower diameter among the genotypes studied. The genotype Merluza $(19.51 \mathrm{~cm})$ followed by Courier $(19.34 \mathrm{~cm})$ produced significantly bigger sized flowers than any other genotypes. The smaller sized flowers were produced by Navona $(16.41 \mathrm{~cm})$.

Varying amount of differences was recorded among the different Asiatic lily genotypes for flower stalk length. It was maximum in the genotype Mestre $(75.87 \mathrm{~cm})$ which was superior over other genotypes, whereas it was recorded minimum in Navona $(34.77 \mathrm{~cm})$.

The significantly higher number of florets recorded in the genotype Pirandeu and was superior compared to all other genotypes studied. However, no significant differences were found within the genotypes of Asiatic lily for number of spikes per square meter. Wide variation in floral parameters has been reported by Dhiman (2003), Sloan and Harkness (2005), Rashmi (2006), Sindhu (2006) and Chitra and Rajamani (2009).

The genotype Pirandeu extended its vase life maximum up to (12.37 days) and found significantly superior over other genotypes and it was found to be on par with Pavia (12.17 days) whereas, minimum number of days was recorded in Navona (7.73 days). This could be due to the presence of more number of buds in flower spike which help the spike to retain attractiveness for a longer period and also might be due to inherent differences among the genotypes. Similar such results were also obtained by Song et al., (1996) and Susan (2003).

Variation in vase life could also be attributed to the increased accumulation of carbohydrates since, these genotypes could produce more number of leaves and higher chlorophyll content, which might have led to increased photosynthesis and increased carbohydrates. Similar variations for vase life were also observed previously by Mahesh (1996) and Krishnappa et al., (2000).

The best cultivar is decided on the basis of number of buds per spike and its quality. The data recorded on yield components viz., number of florets per spike and number of spikes per square meter as influenced by different Asiatic lily genotypes are presented in the Table 4 . The perusal data presented revealed that, the significantly higher (5.00) number of florets recorded in the genotype Pirandeu and was superior compared to all other genotypes studied and the genotype Advantage (2.80) recorded minimum number of florets.

The significant differences were found within the genotypes of Asiatic lily for number of spikes per square meter. The number of spikes per square meter in different genotypes ranged from 16.67 to 24.00. The genotype Pirandeu, CEB Dazzle, Dazzle, Courier, Pavia and Tresor recorded maximum number of spikes per square meter (24.00) while, the genotype Batistero recorded the minimum number (16.67). The increase in flower yield might be attributed by more number of leaves per plant and chlorophyll content in the leaves that would have resulted in production and accumulation of maximum photosynthates and their utilization for build-up of new cells, thereby increasing the production of more number of buds per spike.

The results are in accordance with the findings of Pandey et al., (2010) and Rajivkumar et al., (2010). The variation in the flower yield might 
be due to their genetic makeup. The results are in accordance with the findings of Vikas (2009), Pandey et al., (2010) and Rajivkumar et al., (2010).

The flowering and quality parameters are recorded maximum in the genotype Mestre which was superior over other genotypes. The stalk length is very important parameter which decides the quality of cut flowers. The differences among the genotypes of Asiatic lily for flower yield and quality might be due to their genetic characters of particular genotype. The significantly higher number of florets recorded in the genotype Pirandeu and was superior compared to all other genotypes studied.

\section{References}

Chitra, R. and Rajamani, K., 2009. Evaluation of different glory lily (Gloriosa superba L.) genotypes for vegetative, floral and yield characters. Agric. Sci. Digest, 29 (3): 190-193.

Dhiman, M. R., 2003. Evaluation of Lilium hybrids under Kullu conditions. J. Orn. Hort. (New Series), 6 (2): 154-155.

Krishnappa, K. S., Shivreddy, N. and Anjanappa, 2000. Effect of floral preservatives on the vase life of Carnation cut flower cultivars. Karnataka J. Agric. Sci., 13(2): 395-400.

Mahesh, K., 1996. Variability studies in Carnation (Dianthus caryophyllus L.). M.Sc. Thesis, University of Agric. Sci., Bangalore.

Pandey, R. K., Dogra, S., Jamwal, S. and Bhat, D., 2010, Performance of Asiatic lily under Jammu conditions. Environment and Ecology, 28(2): 775-776.

Rajivkumar, Bidyut, C., and Patel, V. V., 2010, Evaluation of Asiatic lilium under subtropical mid hills of Meghalaya. J. Orn. Hort., 13(4): 257-260.

Rashmi, L., 2006. Evaluation of promising hybrids of gladiolus, M.Sc. (Agri.) Thesis, Uni. Agric. Sci., Dharwad.

Sindhu, S. S., 2006, Evaluation of Lilium cultivars under North Indian conditions. Haryana J. Hort. Sci., 35(3\&4): 270.

Sloan, R. C. and Harkness, S. S., 2005. Hybrid lily cultivar evaluation. Mississippi Agriculture \& Forestry Experiment Station Information Bulletin, 419: 267275.

Song, C., Bang, C., Chung, S., Kim, Y., Lee, J. and Lee, D., 1996, Effects of postharvest pretreatments and preservative solutions on vase life and flower quality of Asiatic hybrid lily. Acta Hort., 414: 277-285.

Susan, H, S., 2003. Role of sugar in the vase solution on postharvest flower and leaf quality of Oriental Lily 'Stargazer', Hort Science, 38(3): 412-416.

Van, T., Jaap, M., Arens, M. S., Ramanna, A., Shahin, N. K., Xie, A., Lim, M. A. and Rodrigo, B., 2011. Lilium. Chapter In: Kole, C. Wealth of Wild Species: Genetic, Genomic and Breeding Resources Volume 9 - Plantation and Orn. Crops. Springer-Verlag Series, in press.

Vikas, H. M., 2009. Performance of dahlia (Dahlia variabilis L.) accessions under transitional zone of Karnataka. M.Sc. Thesis, University of Horticultural Sci. Dharwad.

\section{How to cite this article:}

Chandrashekar, S.Y., B. Hemla Naik, Balaji S. Kulkarni and Jagadeesha, R.C. 2018. Characterization of Asiatic Lily Genotypes for Flowering and Quality Parameters under Protected Conditions. Int.J.Curr.Microbiol.App.Sci. 7(09): 75-81. doi: https://doi.org/10.20546/ijcmas.2018.709.010 